\title{
ANALISIS KINERJA KEUANGAN PADA PT. BANK SULSELBAR CABANG MAKASSAR
}

\author{
Rosalinda Palino \\ (rosalindapalinoo@gmail.com) \\ Institut Bisnis dan Keuangan Nitro Makassar \\ Jl. Prof Abdurahman Basalamah No. 101
}

90231

\begin{abstract}
Abstrak
Peranan bank sebagai agen pembangunan yaitu sebagai lembaga yang bertujuan mendukung pelaksanaan pembangunan nasional, mempunyai kegiatan utama yaitu menghimpun dan menyalurkan dana. Dalam hal ini laba dapat digunakan sebagai ukuran dari prestasi yang dicapai dalam suatu perusahaan. Kesehatan suatu bank merupakan modal utama bagi bank karena jika bank tersebut dikatakan sehat maka masyarakat akan percaya pada bank tersebut dan kemudian masyarakat mau untuk menyimpan uang di bank tersebut. Selain hal tersebut, bank yang memiliki kesehatan yang baik dapat menyalurkan dana dari masyarakat kepada masyarakat. Tujuan penelitian dilakukan untuk mengukur dan menganalisis kinerja keuangan PT. Bank Sulselbar cabang Makassar apakah dalam keadaan sehat. Sumber data yang diperoleh melalui survey langsung ke lokasi ang berkaitan dengan masalah yang dibahas serta dokumen-dokumen sebagai bukti pendukung.

Kata kunci : Kinerja Keuangan, kesehatan Bank
\end{abstract}

\section{PENDAHULUAN}

\section{Latar Belakang}

Krisis ekonomi dan moneter yang melanda Indonesia mengakibatkan menurunnya nilai tukar rupiah yang sangat tajam terhadap dollar Amerika. Demikian pula tingkat inflasi yang terjadi, kondisi krisis tersebut mengakibatkan dampak yang luas terhadap sendi-sendi perekonomian dan dunia perbankan. Makin tinggi peradaban dan perkembangan yang ada dalam suatu masyarakat maka semakin beragamlah kebutuhan itu. Manusia tidak selalu puas dengan apa yang telah dicapai dan berusaha untuk memperoleh sesuatu yang lebih baik. 
keuangan merupakan salah satu dasar dalam penilaian kondisi keuangan perusahaan serta perkembangannya adalah dengan menggunakan instrumeninstrumen pengukuran tertentu. Instrumen yang digunakan sebagai alat analisis tertentu yang dimaksud adalah rasio-rasio keuangan. Rasio merupakan gambaran suatu hubungan dari dua unsur yang secara matematis memberikan gambaran kepada analis tentang baik buruknya suatu keadaan atau posisi keuangan suatu perusahaan.

Bank sebagai lembaga keuangan dengan usaha utamanya memberikan jasa dibidang perbankan. Peran perbankan dalam menghimpun dana masyarakat diperlukan suatu kondisi perbankan yang sehat serta tersedianya produk jasa perbankan yang menarik minat masyarakat. Bank mempunyai kepentingan untuk menjaga dana tersebut agar kepercayaan masyarakat tidak disia-siakan.

Kinerja merupakan salah satu faktor penting yang menunjukkan efektifitas dan efisiensi suatu organisasi dalam rangka mencapai tujuannya. Penilaian kinerja dimaksudkan untuk menilai keberhasilan suatu organisas.

Di antara berbagai bank yang ada saat ini di Sulawesi Selatan pada umumnya adalah PT Bank Sulselbar yang merupakan salah satu bank yang telah memegang peran penting terhadap kemajuan daerah sejak mulai didirikannya. Keistimewaan utama PT Bank Sulselbar adalah sebagai pemegang kas daerah dan menjadi salah satu sumber pendapatan asli daerah melalui berbagai produk perbankan yang dikeluarkannya.

Hasil penelitian Kusumo (2008) tentang Analisis Kinerja Keuangan Bank Syariah Mandiri Periode 2002 - 2007 (dengan Pendekatan PBI No. 9/1/PBI/2007) menunjukkan bahwa rasio yang memiliki perbedaan yang signifikan antara bank bermasalah dengan bank tidak bermasalah adalah CAR, APB, NPL, PPAPAP, $R O A$, NIM serta BOPO.

Berdasarkan penjelasan latar belakang diatas maka penulis tertarik untuk melakukan penelitian mengenai "ANALISIS KINERJA KEUANGAN PADA PT. BANK SULSELBAR CABANG MAKASSAR" 


\section{Rumusan Masalah}

Berdasarkan uraian pada latar belakang, maka rumusan masalah dalam penulisan ini adalah Sejauh mana kinerja keuangan pada Bank Sulselbar cabang Makassar berada pada kondisi sehat?

\section{Tujuan Dan Kegunaan Penelitian}

1. Tujuan Penelitian

Untuk mengetahui dan menganalisis pengaruh kinerja keuangan pada Bank Sulselbar cabang makassar .

2. Kegunaan Penelitian

a. Bagi Dunia Perbankan

Untuk memberikan masukan yang berguna agar mendukung kinerja keuangan perusahaan kearah yang lebih baik lagi.

b. Bagi Peneliti

Penelitian ini diharapkan dapat memperluas pengetahuan dan wawasan peneliti mengenai kinerja keuangan perbankan baik perbankan syariah maupun perbankan konvensional.

c. Manfaat teoritis :

- Sebagai bahan pertimbangan perusahaan dalam menerapkan sistem kinerja keuangan yang baik.

- Sebagai bahan informasi bagi perusahaan dalam proses pengambilan keputusan yang menyangkut hal tentang kinerja keuangan pada masa yang akan datang

\section{TINJAUAN PUSTAKA}

\section{A. Bank}

\section{Pengertia Bank}

Sejarah dikenalnya asal mula kegiatan perbankan dimulai dari jasa penukaran uang. Oleh karena itu bank dikenal sebagai tempat menukar uang atau sebagai meja tempat menukarkan uang. Dalam sejarah para pedagang dari berbagai kerajaan melakukan transaksi dengan menukarkan uang, di mana 
penukaran uang dilakukan antar mata uang kerajaan yang satu dengan mata uang kerajaan yang lain. Kegiatan penukaran uang ini sekarang dikenal dengan perdagangan valuta asing (money changer).

Mendengar kata Bank sebenarnya tidak asing lagi bagi kita, terutama yang hidup di perkotaan. Bahkan di pedesaan sekalipun saat ini kata Bank bukan merupakan kata yang asing dan aneh. Menyebut kata bank setiap orang selalu mengaitkannya dengan uang. Sehingga selalu saja ada anggapan bahwa yang berhubungan dengan bank selalu ada kaitannya dengan uang. Hal ini tidak salah, karena Bank merupakan lembaga keuangan atau perusahaan yang bergerak di bidang keuangan. Sebagai lembaga keuangan Bank menyediakan berbagai jasa keuangan. Di Negara- negara maju, bank bahkan sudah merupakan kebutuhan utama bagi masyarakat setiap kali bertransaksi.

Dendawijaya (2008 : 25) mendefinisikan bahwa bank adalah suatu badan usaha yang tugas utamanya sebagai lembaga perantara keuangan (financial intermediaries), yang menyalurkan dana dari pihak yang berkelebihan dana (idle fund/surplus unit) kepada pihak yang membutuhkan dana atau kekurangan dana (deficit unit) pada waktu yang ditentukan.

Sedangkan menurut Suyatno, dkk. (2007: 1) bahwa bank adalah suatu jenis lembaga keuangan yang melaksanakan berbagai macam jasa, seperti memberikan pinjaman, mengedarkan mata uang, pengawasan terhadap mata uang, bertindak sebagai tempat penyimpanan benda-benda berharga, membiayai usaha perusahaan-perusahaan dan lain-lain.

Hasibuan (2008: 1) mendefinisikan bahwa bank adalah dana usaha yang menghimpun dana dari masyarakat dalam bentuk simpanan dan menyalurkannya kepada masyarakat dalam bentuk kredit dan/atau bentukbentuk lainnya dalam rangka meningkatkan taraf hidup rakyat banyak.

Kemudian menurut Undang-undang Nomor 10 tahun 1998 yang dimaksud dengan bank adalah badan usaha yang menghimpun dana dari masyarakat dalam bentuk simpanan dan menyalurkannya ke masyarakat dalam 
bentuk kredit dan atau bentuk-bentuk lainnya dalam rangka meningkatkan taraf hidup rakyat banyak.

Berdasarkan definisi umum yang dimaksud dapat disimpulkan bahwa bank merupakan lembaga keuangan yang kegiatannya adalah :

- Menghimpun dana (uang) dari masyarakat dalam bentuk simpanan, maksudnya dalam hal ini bank sebagai tempat menyimpan uang atau berinvestasi bagi masyarakat. Tujuan utama masyarakat menyimpan uang biasanya adalah untuk keamanan uangnya. Sedangkan tujuan kedua adalah untuk melakukan investasi dengan harapan memperoleh bunga dari hasil simpanannya.

- Menyalurkan dana ke masyarakat, maksudnya adalah bank memberikan pinjaman (kredit) kepada masyarakat yang mengajukan permohonan. Dengan kata lain bank menyediakan dana bagi masyarakat yang membutuhkannya. Pinjaman atau kredit yang diberikan dibagi dalam berbagai jenis sesuai dengan keinginan nasabah. Tentu saja sebelum kredit diberikan bank terlebih dahulu menilai apakah kredit tersebut layak diberikan atau tidak.

- Memberikan jasa-jasa bank lainnya, seperti pengiriman uang (transfer), penagihan surat-surat berharga yang berasal dari dalam kota (clearing), penagihan surat-surat berharga yang berasal dari luar kota dan luar negeri (inkaso), letter of credit (L/C), safe deposit box, bank garansi, bank notes, travelers cheque dan jasa lainnya.

\section{Pengertian Laporan Keuangan}

Laporan keuangan merupakan alat yang sangat penting untuk memperoleh informasi sehubungan dengan posisi keuangan dan hasil yang telah dicapai oleh perusahaan yang bersangkutan. Suatu laporan keuangan yang menggambarkan kinerja operasional suatu perusahaan operasi sepanjang waktu disebut income statement (laporan laba rugi). Laporan keuangan yang menggambarkan posisi keuangan dari operasional perusahaan pada titik waktu tertentu disebut balance sheet (neraca keuangan).

Keterbatasan laporan keuangan tidak akan mengurangi arti nilai keuangan secara langsung karena hal ini memang harus dilakukan agar dapat menunjukkan kejadian yang mendekati sebenarnya, meskipun perubahan berbagai kondisi dari 
berbagai sektor terus terjadi. Artinya selama laporan keuangan disusun sesuai dengan aturan yang telah ditetapkan, maka inilah yang dianggap telah memenuhi syarat sebagai suatu laporan keuangan.

Susanto (2005 : 3) mengemukakan bahwa : "Laporan keuangan ialah neraca dan perhitungan rugi-laba serta segala keterangan-keterangan yang dimuat dalam lampiran-lampirannya antara lain laporan sumber dan penggunaan dana."

Kasmir (2008: 7) berpendapat bahwa : "Laporan keuangan adalah laporan yang menunjukkan kondisi keuangan perusahaan pada saat ini atau dalam suatu periode tertentu Kondisi perusahaan terkini adalah keadaan keuangan perusahaan pada tanggal tertentu (untuk neraca) dan periode tertentu (untuk laporan laba brugi)". Laporan keuangan bertujuan untuk memberikan informasi keuangan suatu perusahaan, baik pada saat tertentu maupun pada periode tertentu. Atau laporan keuangan mampu memberikan informasi keuangan kepada pihak dalam dan luar perusahaan yang memiliki kepentingan terhadap perusahaan."

Prof. Dr. Manahan P. Tampubolon (2013:19) berpendapat bahwa : Laporan keuangan suatu korporasi lazimnya meliputi: neraca (balance sheets) laba rugi (income statement) dan laporan sumber dan penggunaan dana (sources and uses fund). Lapran keuangan ini dingunakan untuk berbagai macam tujuan. Setiap penggunaan yang berbeda membutuhkan informasi yang berda pula".

Oesman dalam Daga (2021 : 3) mengemukakan bahwa pemasaran merupakan suatu fungsi secara organisasi dan seperangkat proses dari penciptaan, komunikasi dan penyampaian nilai kepada pelanggan dan untuk mengelola kerelasiaan pelanggan dengan cara yang bermanfaat baik bagi organisasi maupun bagi stake stakeholders

Ditinjau dari segi intern perusahaan, laporan keuangan dapat digunakan untuk berbagai tujuan. Data laporan keuangan terutama akan memberikan informasi sebagai bahan analisa dan bahan interprestasi untuk mengadakan evaluasi terhadap aktivitas perusahaan. Laporan keuangan akan menunjukkan sampai seberapa jauh efisiensi pelaksanaan kegiatan serta perkembangan perusahaan yang telah dicapai.

\section{Pengertian Kinerja Keuangan}


Agar perusahaan dapat tetap berjalan sesuai harapan, biasanya manajemen membagi-bagi tugas, memecah-mecah organisasi perusahaan menjadi divisi-divisi, dan menetapkan seorang yang bertanggung-jawab untuk setiap divisi tersebut.

Zarkasyi (2008 : 48) bahwa : "Kinerja keuangan merupakan sesuatu yang dihasilkan oleh suatu organisasi dalam periode tertentu dengan mengacu pada standar yang ditetapkan."

Menurut Mathis dan Jackson ( 2006:382 ), "Penilaian kinerja (performance appraisal) adalah proses mengevaluasi seberapa baik karyawan melakukan pekerjaan mereka jika dibandingkan dengan seperangkat standar, dan kemudian mengkomunikasikan informasi tersebut kepada karyawan". Penilaian kinerja juga disebut pemeringkatan karyawan, evaluasi karyawan, tinjauan kerja, evaluasi kinerja, dan penilaian hasil

Menurut Drs. Jumingan ( 2016:239 ) "Kinerja perusahaan merupakan gambaran prestasi yang dicapai perusahaan dalam operasionalnya, baik menyangkut aspek keuangan, pemasaran, penghimpunan dan penyaluran dana, teknologi maupun sumber daya manusia".

Menurut Indra Bastian ( 2006:317 ) Dalam Bukunya, Akuntansi Sektor Publik Di Indonesia"menjelaskan bahwa: "kinerja adalah gambaran tingkat pencapaian pelaksanaan suatu kegiatan/program/kebijaksanaan dalam mewujudkan sasaran, tujuan misi dam visi organisasi yang tertuang dalam perumusan skema strategi (strategic planning) suatu organisasi". Jadi kinerja adalah suatu alat yang digunakan untuk mengetahui kesehatan suatu perusahaan. Dan alat utamanya untuk mengetahui sehatnya suatu perusahaan adalah laporan keuangan.

Tolak ukur ini tidak mampu mengungkapkan sebab-sebab dari keberhasilan perusahaan dan hanya melaporkan apa yang terjadi di masa lalu. Penilaian ini bisa jadi sangat menyesatkan karena adanya

kemungkinan kinerja keuangan yang baik saat ini diciptakan dengan mengorbankan kepentingan-kepentingan jangka panjang perusahaan. Sebaliknya kinerja keuangan yang kurang baik saat ini terjadi karena perusahaan melakukan investasi-investasi demi kepentingan jangka panjang. Selain itu pengukuran kinerja yang hanya berfokus pada kinerja keuangan cenderung mengabaikan kinerja non 
keuangan seperti kepuasan konsumen, produktivitas dan biaya efektif, peningkatan kemampuan operasional, pengenalan jasa atau produk baru, keahlian karyawan, integritas manajemen, jaringan pemasok, basis pelanggang, saluran distribusi dan nama baik perusahaan yang merupakan asset tidak berwujud (intangible asset) yang sangat berperan dalam menentukan kesuksesan perusahaan.

\section{Pengertian Dan Jenis-Jenis Rasio Keuangan}

Agar kita tidak salah dalam menempatkan dana di bank, Menurut Boy Loen dan Sonny Ericson (2008 : 118) kita perlu mengetahui kinerja bank tersebut, dan untuk mengetahui kinerja suatu bank, umumnya alat yang digunakan adalah dengan melakukan analisa ratio kinerja bank, yaitu dengan melakukan analisis rasio likuiditas, rentabilitas dan solvabilitas.

Rasio keuangan dapat disajikan dalam dua cara. Yang pertama untuk membuat perbandingan keadaan keuangan pada saat yang berbeda. Dan kedua, untuk membuat perbandingan keadaan keuangan dengan perusahaan lain. Analisis rasio merupakan alat analisis yang berguna apabila dibandingkan dengan rasio standar yang lazim digunakan. Yang pertama adalah rasio yang sama dari laporan keuangan tahun-tahun yang lampau. Yang kedua adalah rasio dari perusahaan lain yang mempunyai karakteristik yang sama dengan perusahaan yang dianalisis.

Pengertian rasio keuangan dikemukakan oleh Harahap (2007 : 297) mengemukakan bahwa Rasio keuangan adalah angka yang diperoleh dari hasil perbandingan dari satu pos laporan keuangan dengan pos lainnya yang mempunyai hubungan yang relevan dan signifikan (berarti).

Menurut Irham Fahmi (2014:44) "Rasio keuangan atau financial ratio ini sangat penting gunanya untuk melakuan analisa terhadap kodisi keuangan perusahaan. Bagi investor jangka pendek dan menengah pada umumnya lebih banyak tertarik kepada kondisi keuangan jangka pendek dan kemampuan perusahaan untuk membayar dividen yang memadai".

Menurut Munawir (2007:64) Rasio menggambarkan suatu hubungan atau perbandingan (mathematical) antara jumlah dengan jumlah yang lain dan dengan menggunakan alat analisa, berupa rasio ini akan dapat menjelaskan atau memberi gambaran kepada penganalisa tentang baik atau buruknya keadaan atau posisi 
keuangan suatu perusahaan terutama apabila rasio angka tersebut dibandingkan dengan angka rasio perbandingan yang digunakan sebagai standar"

Menurut Arief Sugiono dan Edi Untung (2016:53) "Analisa rasio merupakan suatu angka yang menunjukan hubungan antara unsur-unsur dalam laporan keuangan. Hubungan tersebut dinyatakan dalam bentuk matematis yang sederhana."

- Rasio Likuiditas

Suatu bank dikatakan likuid apabila bank yang bersangkutan dapat memenuhi kewajiban hutang-hutangnya, dapat membayar kembali semua deposannya, serta dapat memenuhi permintaan kredit yang diajukannya tanpa terjadi penangguhan.

- Rasio Solvabilitas

Analisa solvabilitas bank atau secara teknis disebut juga Analysis of Bank Capital ini akan membahas secara bertahap tentang fungsi dari Bank Capital, cara pengukuran kebutuhan modal dan cara perhitungan ratio dari solvabilitas suatu bank, yang dikutip dari Muljono (2004 :

110)

- Ratio efisiensi usaha

Dengan ratio aktivitas, dapat diukur tingkat kegiatan suatu perusahaan apakah efisiensi atau tidak.

\section{Hubungan Ratio Dan Kinerja Keuangan}

Menurut irham fahmi (2014:46) "Rasio keuangan dan kinerja perusahaan mempunyai hubungan yang erat. Rasio keuangan ada banyak jumlahnya dan setiap rasio itu mempunyai kegunaan masing-masing. Bagi investor ia akan melihat rasio dengan penggunaan yang paling sesuai dengan analisis yang ia lakukan. Jika rasio tersebut tidak mempresentasikan tujuan analisis yang akan ia lakukan maka rasio tersebut tidak akan dipergunakan, karena dalam konsep keuangan dikenal dengan fleksibelitas, artinya rumus atau berbagai bentuk formula yang dipergunakan haruslah disesuaikan dengan kasus yang diteliti.Karena kita tidak bisa menganalisasikan seluruh rumus yang ada adalah cocok pada semua kasus yang diteliti. Atau dalam istilah pakar keuangan bahwa pasar adalah laboratorium yang paling bagus untuk menguji segala kemampuan dan analisa yang dimiliki, maka 
segala kepemilikan formula dan berbagai pemikiran yang kita miliki akan terbukti pada saat kita menguji di pasar, seperti profit atau rugikah yang akan terjadi nantinya".

\section{Manfaat Analisis Ratio Keuangan}

Menurut irham fahmi (2014:47) Adapun manfaat yang bisa diambil dengan dipergunakannya rasio keuangan yaitu:

- Analisis rasio keuangan sangat bermanfaat untuk dijadikan sebagai alat menilai kinerja dan prestasi perusahaan.

- Analisis rasio keuangan sangat bermanfaat bagi pihak manajemen sebagai rujukan untuk membuat perencanaan.

- Analisis rasio keuangan dapat dijadikan sebagai alat untuk mengevaluasi kondisi suatu perusahaan dari perspektif keuangan.

- Analisis rasio keuangan juga bermanfaat bagi para kreditor dapat digunakan untuk memperkirakan potensi risiko yang akan dihadapi dikaitkan dengan adanya jaminan kelangsungan pembayaran bunga dan pengambilan pokok pinjaman.

- Analisis rasio keuangan dapat dijadikan sebagai penilaian bagi pihak stakeholder organisasi.

\section{Tujuan Laporan Keuangan}

Seperti diketahui bahwa setiap laporan keuangan yang dibuat sudah pasti memiliki tujuan tertentu. Dalam praktiknya terdapat beberapa tujuan yang hendak dicapai, terutama bagi pemilik usaha dan manajemen perusahaan. Tujuan laporan keuangan adalah untuk memberikan informasi kepada pihak-pihak yang membutuhkan tentang kondisi suatu perusahaan dari sudut angka-angka dalam suatu moneter dan menyediakan informasi yang menyangkut posisi keuangan, kinerja serta perubahaan posisi keuangan suatu perusahaan yang bermanfaat bagi sejumlah besar pemakai dalam pengambilan keputusan ekonomi.

Menurut Kasmir, dalam bukunya "Analisis Laporan Keuangan" (2012:11) berikut ini beberapa tujuan pembuatan atau penyusunan laporan keuangan yaitu :

- Memberikan informasi tentang jenis dan juga aktiva (harta) yang dimiliki perusahaan pada saat ini 
- Memberikan informasi tentang jenis dan jumlah kewajiban dan modal yang dimiliki perusahaan pada saat ini.

- Memberikan informasi tentang jenis dan julmlah pendapatan yang diperoleh pada suatu periode tertentu.

- Memberikan informasi tentang jumlah biaya dan jenis biaya yang dikeluarkan perusahaan pada periode tertentu.

- Memberikan informasi tentang perubahan-perubahan yang terjadi pada aktiva, pasiva dan modal perusahaan.

- Memberikan informasi tentang kinerja manajemen perusahaan dalam suatu periode

- Memberikan informasi tentang catatan-catatan atas laporan keuangan

- Informasi keuangan lainnya

\section{Kegunaan Laporan Keuangan}

Berdasarkan konsep keuangan maka laporan keuangan sangat diperlukan untuk mengukur hasil usaha dan perkembangan perusahaan dari waktu ke waktu dan untuk mengetahui sudah sejauh mana perusahaan mencapai tujuannya. Bahwa laporan keuangan pada dasarnya merupakan hasil proses akuntansi yang dapat digunakan sebagai alat untuk berkomunikasi antara data keuangan atau aktivitas suatu perusahaan dengan pihak-pihak yang berkepentingan dengan data atau aktivitas suatu perusahaan dengan pihak-pihak yang berkepentingan dengan data atau aktivitas perusahaan tersebut. Sehingga laporan keuangan memegang peranan yang luas dan mempunyai suatu posisi yang mempengaruhi dalam pengambilan keputusan.

\section{Profitabilitas}

Komponen faktor likuiditas meliputi Kewajiban Bersih antar bank yaitu selisih antara kewajiban bank dengantagihan kepada bank lain dan Modal Inti Bank. Penilaian terhadap faktor likuiditas didasarkan pada 2 (dua) rasio, yaitu:

- Rasio Kewajiban Bersih Antar Bank terhadap Modal Inti

- Rasio Kredit terhadap Dana Yang Diterima oleh Bank.

\section{Pengertian Tingkat Kesehatan Bank}

Secara sederhana dapat dikatakan bahwa bank yang sehat adalah bank yang dapat menjalankan fungsi-fungsinya dengan baik. Bank yang sehat adalah bank 
yang dapat menjaga dan memelihara kepercayaan masyarakat, dapat menjalankan fungsi intermediasi, dapat membantu kelancaran lalulintas pembayaran serta dapat dipergunakan oleh pemerintah dalam melaksanakan berbagai kebijakannya, terutama kebijakan moneter. Bank dalam menjalankan fungsi-fungsi tersebut diharapkan dapat memberikan pelayanan yang baik kepada masyarakat serta bermanfaat bagi perekonomian secara keseluruhan.

Tingkat kesehatan bank adalah kemampuan suatu bank untuk melakukan kegiatan operasional perbankan secara normal dan mampu memenuhi semua kewajiban dengan baik dengan cara-cara yang sesuai dengan peraturan perbankan yang berlaku. Menurut surat edaran direksi Bank Indonesia tentang tata cara penilaian tingkat kesehatan bank umum, menyatakan bahwa tingkat kesehatan bank pada dasarnya dinilai dengan pendekatan berbagai faktor yang mempengaruhi kondisi dan perkembangan bank dalam hal ini adalah faktor permodalan, aktiva produktif, faktor rentabilitas, faktor likuiditas dan faktor sensitivitas.

Sedangkan menurut Loen dan Ericson (2008: 129) mengemukakan bahwa tata cara penilaian tingkat kesehatan bank dalam bahasa Inggris disingkat CAMEL, oleh karena itu tata cara penilaian tingkat kesehatan bank dikenal dengan sebutan metode CAMEL, yang dapat diuraikan sebagai berikut :

- Capital (modal bank), yang dinilai adalah pemenuhan terhadap kewajiban penyediaan modal minimum (KPMM) atau yang disebut capital adequacy ratio (CAR).

- Asset (aktiva) yang dinilai adalah kualitas aktiva produktif (KAP) yang terdiri dari :

$$
K A P=\frac{\text { Aktiva Produktif yang diklasifikasi }}{\text { Total Aktiva Produktif }} \times 100 \%
$$

- Management, aspek manajemen diproksikan dengan net profit margin dengan pertimbangan rasio ini menunjukkan bagaimana manajemen mengelola sumbersumber maupun penggunaan atau alokasi dana secara efisien, sehingga nilai rasio yang diperoleh langsung dikalikan dengan nilai bobot CAMEL sebesar 25\%. 
- Earnings (rentabilitas) yang dinilai adalah kemampuan bank dalam menghasilkan laba.

- Liquidity (Likuiditas), yang dinilai adalah kemampuan bank dalam menjaga/ memelihara likuiditas.

\section{Penelitian Terdahulu}

Adapun peneliti yang telah melakukan penelitian terkait, antara lain sebagai berikut :

a. Penelitian yang di lakukan oleh Maith (2013) Tentang Analisis Laporan Keuangan Dalam Mengukur Kinerja Keuangan Pada PT. Mandala Sampoerna Tbk. Berdasarkan rasio likuiditas setiap tahunnya mengalami peningkatan sehingga keadaan perusahaan dikategorikan dalam keadaan baik (liquid). Dari rasio solvabilitas menunjukkan bahwa modal perusahaan tidak lagi mencukupi untuk menjamin hutang yang diberikan oleh kreditor sehingga keadaan perusahaan dikatakan dalam keadaan tidak baik (insolvable). Ditinjau dengan rasio aktivitas menujukkan peningkatan di setiap tahunnya sehingga keadaan perusahaan dikatakan dalam keadaan baik. Berdasarkan rasio profitabilitas menunjukkan adanya peningkatan dari tahun ke tahun sehingga dapat dikatakan keadaan perusahaan berada pada posisi yang baik.

b. Penelitian yang dilakukan oleh setyaningsih dan utami (2013) tentang Analisis Perbandingan Kinerja Keuangan Perbankan Syariah Dengan Perbankan Konvensional. Hasil yang: rasio CAR di PT Bank BRI Tbk terlihat lebih baik dari PT Bank Syariah Muamalat Indonesia Tbk. Ini adalah ditunjukkan dengan nilai yang lebih tinggi dari CAR untuk periode 2009 - 2011 yang dimiliki oleh PT Bank BRI Tbk. Rasio NPL di PT Bank Syariah Muamalat Indonesia Tbk lebih baik dari PT Bank BRI Tbk. Hal ini ditunjukkan dengan nilai yang lebih rendah dari NPL selama periode tersebut 2009 - 2011. rasio ROA pada PT Bank BRI Tbk terlihat lebih baik dari pada PT Bank Syariah Muamalat Indonesia Tbk. Hal ini ditunjukkan dengan nilai yang lebih tinggi dari ROA selama periode 2009 - rasio BOPO 2011. di PT Bank BRI Tbk lebih baik dari PT Bank Syariah Muamalat Indonesia Tbk. Hal ini ditunjukkan dengan nilai yang lebih rendah dari BOPO lebih periode 2009 Rasio Likuiditas 2011. PT Bank BRI Tbk lebih baik dari kinerja keuangan dibandingkan dengan PT Bank 
Syariah Muamalat Indonesia Tbk. Hal ini ditunjukkan baik pada nilai LDR. Selama periode 2009 - 2011 nilai LDR di PT Bank BRI tbk rendah.

c. Penelitian yang di lakukan oleh Sembiring (2003) tentang Kinerja Keuangan, Political, Vsibility, Ketergantungan Pada Hutang, Dan Pengungkapan Tanggung Jawab Sosial Perusahaan. Hasil penelitian menunjukkan bahwa ukuran perusahaan memiliki positif yang signifikan pengaruh terhadap pengungkapan tanggung jawab sosial perusahaan pada tingkat signifikansi $5 \%$ dan laba per-saham, publik kepemilikan, dan ketergantungan pada utang memiliki pengaruh negatif yang signifikan pada tanggung jawab sosial perusahaan pengungkapan pada tingkat $10 \%$ signifikansi. Hasil ini umumnya bertepatan dengan temuan penelitian lain pada perusahaan tanggung jawab pengungkapan sosial.

\section{B. Kerangka Pikir}

Gambar 2.1

Kerangka Pikir

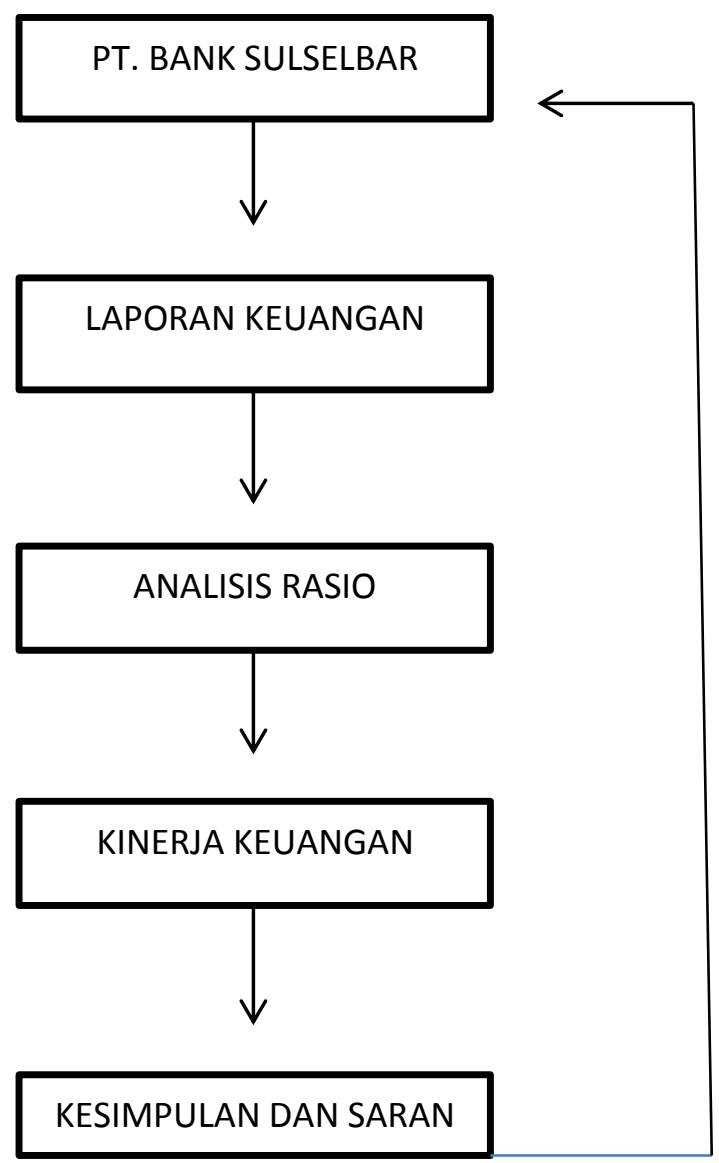




\section{Keterangan :}

Gambar 2.1 mengambarkan peneliti melakukan penelitian pada PT. Bank Sulselbar. Dimana penulis ingin mengetahui pengaruh profitabilitas terhadap nilai perusahaan pada PT. Bank Sulselbar. Sehingga diharapkan penulis dapat mengambil kesimpulan dan memberikan saran kepada investor dalam mempertimbangkan untuk melakukan investasi.

\section{METODE PENELITIAN}

\section{A. Lokasi Dan Waktu Penelitian}

Penelitian ini dilaksnakan pada PT. Bank Sulselbar cabang Makassar yang berlokasi di jalan urip Sumaharjo No.8, Karuwisi Utara, kec. Makassar, Sulawesi selatan. Waktu yang dibutuhkan untuk melakukan penelitian ini diperkirakan kurang lebih satu bulan.

\section{B. Jenis Dan Sumber Data}

\section{Jenis Data}

a. Data kualitatif, analisis yang dilakuakan terhadap data-data yang non angka seperti hasil wawancara, atau catatan laporan bacaan dan buku-buku, artikel. Data-data ini yang digunakan untuk mengembangkan analisis itu sendiri. Pada dasarnya kegunaan data tersebut adalah sebagai dasar objektif dalam proses pembuatan keputusan-keputusan atau kebijaksanaan-kebijaksanaan dalam rangka memecahkan persoalan yang ada

b. Data kuantitatif, analisis yang dilakukan terhadap data yang berbentuk angka dan diperoleh dalam bentuk laporan keuangan.

\section{Sumber Data}

a. Data primer, yaitu data yang diperoleh langsung dari observasi dan wawancara laangsung pada pihak yang berwenang. 
b. Data sekunder, yaitu data yang diperoleh dokumen-dokumen dan bahan tertulis, baik yang berasal dari dalam perusahaan maupun dari luar dalam perusahaan yang berhubungan dengan masalah yang akaan dibahas.

\section{Metode Dan Teknik Pengumpulan Data}

1. Metode Pengumpulan Data

Metode pengumpulan data yang digunakan yaitu :

\section{a. Wawancara}

Wawancara merupakan alat.cheking atau pembuktian terhadap informasi atau keterangan yang diperoleh sebelumnya. Menurut Sugiyono (2010:317) wawancara merupakan..pertemuan dua orang untuk bertukar infomasi dan ide melalui tanya jawab, sehingga dapat dikonstruksikan makna dalam suatu topik tertuntu. Sedangkan menurut Esterberg dalam sugiyono (2015:72) wawancara adalah pertemuan yang dilakukan oleh dua orang untuk bertukar informasi maupun suatu ide dengan cara tanya jawab,.sehingga dapat dikerucutkan menjadi sebuah kesimpulan atau makna dalam topik tertentu.

\section{b. Observasi}

Observasi merupakan kegiatan yang melibatkan seluruh kekuatan indera seperti pendengaran, penglihatan, perasa, sentuhan dan cita rasa berdasarkan pada faktafakta peristiwa empiris. Prinsip umum dalam melakukan observasi adalah pengamat tidak memberikan perlakuan

tertentu kepada subjek yang diamati, melainkan membiarkan subjek yang sedang diamati berucap dan bertindak sama persis dengan kegiatan mereka sehari-hari (Anggito dan Setiawan, 2018:142).

\section{Teknik pengumpulan data}

Teknik yang digunakan dalam penelitian ini dapat diuraikan sebagai berikut :

a. Data kata-kata (verbal) berupa apa yang dikatakan informan tentang pengaruh kinerja keuangan pada PT. Bank Sulselbar cabang Makassar.

b. data non verbal merupakan apa yang dipikirkan, dipercaya, diketahui dan disikapi oleh informan dalam kegiatannya.

c. Data fotografi, data ini membantu memberikan gambaran sesuai perilaku. 
d. Data pustaka berupa pengumpulan data dengan cara menelaah dan mempelajari literatur-literatur, buku dan bahan pustaka lainnya yang menyangkut teori-teori yang relevan dengan masalah yang akan dibahas.

Teknik pengumpulan data dilakukan melalui wawancara secara mendalam dengan instrumen yang tidak terstruktur. Lamanya waktu wawancara tidak dibatasi, namun tetap memperhatikan etika dan kondisi informan. Meskipun instrumen wawancara tidak terstruktur, peneliti menyiapkan konsep yang akan ditanyakan, namun dalam prakteknya peneliti akan membuat wawancara mengalir dan berkembang. Teknik pengumpulan data non verbal dilakukan dengan melalui observasi dan dokumentasi. Penelitian ini akan dibantu oleh perekam suara dan catatan harian observasi.

\section{Informan Penelitin}

Pada penelitian kualitatif, tidak dikenal adanya populasi dan sampel tetapi dinamakan informan. Informan adalah orang yang diberikan pertanyaan untuk mendapatkan informasi mengenai fokus penelitian. Informan ditentukan dengan teknik purvosive, yaitu teknik penentuan subjek (informan) yang berdasarkan kriteria dan tujuan dari penelitian ini. Kriteria ini ditentukan oleh peneliti, dimana yang dipilih peneliti adalah salah satu karyawan di bidang Account Officer atau Analis Kredit PT Bank Sulselbar (Persero), Tbk Makassar dengan tidak berdasarkan jenis kelamin dan mereka siap menjadi informan. Informan yang digunakan adalah 1 (satu) orang dan memungkinkan

adanya penambahan jika tujuan penelitian belum tercapai.

Tahapan untuk memperoleh informan adalah :

1. Peneliti mencari informasi karyawan Bank BRI sesuai kebutuhan peneliti

2. Peneliti kemudian menyeleksi calon informan tersebut dengan melihat kesesuaian kriteria, dan juga berdasarkan sifat keterbukaan informan.

3. Peneliti mengajukan pertanyaan untuk kesediaan mereka melakukan wawancara.

\section{E. Instrumen penelitian}

Instrumen penelitian yang digunakan berbentuk pertanyaan terbuka, dimana pertanyaan dimulai dengan identifikasi informan. Dimana pertanyaan utamanya 
merupakan pertanyaan yang mengarah pada strategi pengembagan kinerja keuangan pada PT. Bank sulselbar cabang makassar. Pertanyaan tambahan selanjutnya dimungkinkan dari gambaran yang diberikan informan selain pertanyaan utama seperti yang dijelaskan sebelumnya. Adapun daftar pertanyaan sebagai berikut :

1. Strategi apa yang digunakan dalam meningkatan kinerja keuangan pada PT. Bank Sulselbar Makassar?

2. Bagaimana penerapan metode CAMELS (Capital, Manajemen, Earning, Liquidity, and sensitivity to market risk) dalam menentukan kesehatan PT. Bank Sulselbar ?

3. Bagaimana proses evaluasi strategi yang diguanakan dalam peningkatan pengembangan kinerja keuangan pada PT. Bank Sulselbar Makassar?

Keseluruhan inti pertanyaan tersebut akan dihubungkan dan diselaraskan berdasarkan teori-teori yang ada.

\section{F. Defenisi Operasional}

Penelitian ini merupakan penelitian untuk mengetahui "Analisis Kinerja keuangan dengan menggunakan metode CAMELS pada PT. Bank Rakyat Indonesia (Persero) Tbk". Diperlukan laporan keuangan perusahaan berupa laporan neraca dan laporan laba rugi selama periode lima tahun yaitu periode 2010 sampai dengan 2014. Aspek yang digunakan adalah sebagai berikut:

a. Aspek Permodalan (Capital)

Faktor permodalan merupakan faktor yang sangat penting bagi bank dalam rangka pengembangan usaha serta untuk mencari risiko kerugian, baik perlindungan terhadap pemilik dana yang ditempatkan pada tabungan, simpanan berjangka juga terhadap risiko pinjaman yang diberikan kepada nasabah. Rumus rasio Capital Adequacy Ratio (CAR) adalah sebagai berikut:

$$
C A R=\frac{\text { Modal Bank }}{\text { ATMR }} \times 100 \%
$$

\section{b. Aspek Kualitas Aktiva (Assets)}

Aktiva produktif yaitu seluruh penanaman modal dalam bentuk rupiah dan valuta asing yang bertujuan untuk mendapatkan penghasilan berdasarkan fungsinya (Siamat, 1995:230). Kualitas aktiva dapat dihitung dengan menggunakan rasio aktiva produktif dan rasio Penyisihan Penghapusan Aktiva Produktif yang dibentuk 
pada penyisihan penghapusan aktiva yang wajib dibentuk. Rumus rasio kualias aktiva yaitu:

$$
K A P=\frac{\text { Aktivitas Produktif yang diklasifikasikan }}{\text { Aktivasi Produktif }} \times 100 \%
$$

Pembentukan penyisihan penghapusan aktiva produktif adalah setiap bank wajib untuk membentuk Penyisihan Penghapusan Aktiva Produktif (PPAP) atau Cadangan Kerugian terhadapa Aktiva Produktif atau Cadangan Piutang Ragu-ragu (CPRR) yang cukup guna menutupi risiko kerugian. Perhitungan terhadap kualitas aktiva dengan menggunakan rasio cadangan penyisihan penghapusan aktiva produktif adalah:

$$
P P A P=\frac{\text { Penyisihan Ph.apa yang dibentuk Bank }}{\text { Penyisihan Ph.apa yang wajib dibentuk Bank }} X 100 \%
$$

\section{c. Aspek Manajemen}

Manajemen dilihat dari kualitas manusia yang mempunyai wawasan dan edukasi para pegawainya dalam menyelesaikan suatu masalah yang terjadi. Pokok penilaian didalam suatu manajemen adalah manajemen permodalan, manajemen aktiva, manajemen umum, manajemen rentabilitas, dan manajemen likuiditas (Martono, 2002). Penilaian kesehatan bank dalam aspek manajemen dilakukan dengan media kuisioner yang ditunjukan bagi pihak manajemen bank terdapat lima risiko yang dapat dinilai yaitu risiko likuiditas, risiko kredit, risiko operasional, risiko hukum, risiko pemilikan dan pengurusan.

Aspek manajemen yang diproksikan dengan net profit margin yang dirumuskan sebagai berikut:

$$
N P M=\frac{\text { Laba Bersih }}{\text { Laba Operasional }} \times 100 \%
$$

\section{d. Aspek Rentabilitas}

Rentabilitas adalah upaya bank dalam menghasilkan laba. Suatu bank yang dikatakan sehat yaitu mempunyai tingkat rentabilitas yang terus meningkat. Penilaian rentabilitas diproksikan dengan ROA dan BOPO adalah sebagai berikut:

$$
R O A=\frac{\text { Laba sebelum pajak }}{\text { rata }- \text { rata aset }} \times 100 \%
$$




$$
B O P O=\frac{\text { Biaya operasional }}{\text { Pendapatan Operasional }} \times 100 \%
$$

\section{e. Aspek Likuiditas}

Likuiditas merupakan kemampuan membayar kewajiban yang segera harus dibayar. Bagi perbankan, rasio likuiditas yang penting adalah rasio yang wajar antara pinjaman yang diberikan dengan modal yang diperoleh Loan to Deposito Ratio (LDR) dan rasio jumlah aktiva lancar terhadap hutang lancar Liquid Assets to Current Liabilities Ratio (LACLR). Rumus rasio likuiditas yang dipakai yaitu rasio LDR yang dapat diproksikan sebagai berikut:

$$
L D R=\frac{\text { Kredit yang diberikan }}{\text { Dana pihak Ketiga }} \times 100 \%
$$

\section{f. Sensitivitas Terhadap Resiko Pasar}

Variable ini merupakan ukuran seberapa besar tingkat sensitivitas sebuah bank terhadap resiko pasar atau market risk. Resiko pasar itu sendiri merupakan akibat pergerakan harga pasar dari portofolio yang dimiliki oleh bank, dan dapat merugikan bank tersebut. Tingkat sensitivitas terhadap resiko pasar ini dapat diukur dengan:

$$
\text { interest ekspense ratio }=\frac{\text { interest ekspense }}{\text { total deposit }} \times 100 \%
$$

\section{G. Analisis Data}

1. Pendekatan Penelitian

Penelitian ini dilakukan dengan menggunakan metode penelitian kualitatif. Dimana kualitatif adalah metode penelitian yang berlandaskan pada filsafat postpositivisme atau interpretif, yang digunakan untuk meneliti pada kondisi objek kunci, pengumpulan data dilakukan secara triangulasi (gabungan observasi, wawancara, dokumentasi), data yang diperoleh cenderung data kualitatif, analisis data bersifat induktif/kualitatif, dan hasil penelitian kualitatif bersifat untuk memahami makna, memahami keunikan, mengkonstruksi fenomena, dan menemukan hipotesis (Sugiyono, 2017:9).

2. Pendekatan Kualitatif Naratif

Pendekatan kualitatif naratif merupakan pendekatan yang dilakukan dengan mempelajari perjalanan kehidupan dari satu orang atau lebih yang kemudian dirangkum dan disusun oleh penelitian menjadi satu laporan yang naratif dan 
kronologis (Sugiyono, 2017:162).

Langkah-langkah dari analisis data yang dilakukan adalah:

1. Mengorganisasikan dan menyiapkan data yang akan dianalisis. Data mentah yang akan dianalisis diorganisasikan berdasarkan tanggal pengumpulan data, sumber data, jenis data, deskripsi data, sifat data.

2. Baca dan melihat seluruh data

Peneliti harus membaca seluruh data yang dikumpul, supaya dapat mengetahui data apa saja yang telah diperoleh, sumber data dan maknanya.

3. Membuat koding seluruh data

Koding adalah proses memberikan tanda terhadap data yang telah dikelompokkan. Kelompok data yang sejenis diberi kode yang sama. Koding dapat dilakukan secara manual atau dengan komputer.

4. Membuat koding sebagai bahan untuk membuat deskripsi melalui koding, peneliti menghasilkan tema-tema atau kategorisasi data penelitian yang merupakan temuan. Berdasarkan tema-tema yang dihasilkan tersebut, selanjutnya peneliti membuat deskripsi secara singkat dan sistematis sehingga tema-tema yang ditemukan menjadi lebih jelas.

\section{H. Sistematika Penulisan}

Untuk memberikan gambaran mengenai keseluruhan penelitian ini, maka penulis menguraikan isi setiap bab yang telah dibahas sebagai berikut:

Bab I merupakan bab pendahuluan meliputi latar belakang, rumusan masalah, tujuan dan kegunaan penelitian.

Bab II merupakan bab tinjauan pustaka yang menguraikan tentang landasan teori dan kerangka pikir.

Bab III merupakan bab metode penelitian meliputi lokasi dan waktu penelitian, jenis dan sumber data, metode dan teknik pengumpulan data, informan penelitian, instrumen penelitian, definisi operasional, analisis data.

\section{KESIMPULAN :}

Berdasarkan hasil penelitian dan pembahasan yang telah disajikan pada bab-bab sebelumnya, maka dapat diambil kesimpulan sebagai berikut : 
Berdasarkan uji secara parsial (uji t), diperoleh hasil bahwa kinerja keuangan berpengaruh positif terhdap kesehatan Bank. 


\section{DAFTAR PUSTAKA}

Daga, Rosnaini. "PENGARUH STRATEGI KEMITRAAN BANK TERHADAP KEPUASAN NASABAH PADA PT. BANK MEGA Tbk. CABANG AHMAD YANI MAKASSAR." (2021).

Fahmi Irham, 2011. Analisis Kinerja Keuangan, Jakarta: CV. Alfabeta.

Gitosudarmo, Indriyo, dan Basri 2002 Manajemen Keuangan, edisi keempat, cetakan pertama, Yogyakarta : BPFE.

Harahap, Sofyan Syafri. 2015. Teori Akuntansi Laporan Keuangan. Jakarta: PT Raja Grafindo Persada.

Harmono.2013.Manajemen Keuangan. Jakarta: PT Bumi Aksara

Jumingan, 2013. Analisis Laporan Keuangan, Jakarta: PT. Bumi Aksara.

Kasmir, SE., MM. 2008, Analisis Laporan Keuangan, edisi pertama, cetakan pertama, Jakarta : Rajawali Pers.

Kasmir, SE., MM. 2010. Manajemen Perbankan. Ed. Revisi, 9. Jakarta: Rajawali Pers.

Maryanto Supriyono. 2010. Buku Pintar Perbankan. Ed.1. Yogyakarta: ANDI.

Mayco D. 2013. Analisis Faktor-Faktor Pembentuk (CAMELS) Pada Perbankan Indonesia (Studi kasus pada Bank yang Terdaftar di BEI). Skripsi Fakultas Ekonomi Universitas Diponegoro.

Munawir, S. 2000. Analisa Laporan Keuangan, Yogyakarta: Liberty Yogyakarta. 
Riyadi, Slamet, 2006, Banking Assets and Liability Management, edisi ketiga, Penerbit : Fakultas Ekonomi Universitas Indonesia, Jakarta.

Rizky M. 2012. Analisis Kinerja Keuangan Dengan Menggunakan Metode CAMEL (Studi kasus pada PT. Bank Sulselbar tahun 2008-2010). Skripsi Fakultas Ekonomi Universitas Hasanuddin. 
